\title{
DESCRIPTION OF A NEW MACROBRACHIUM SPECIES (CRUSTACEA: DECAPODA: CARIDEA: PALAEMONIDAE) FROM A CAVE IN GUANGXI, WITH A SYNOPSIS OF THE STYGOBIOTIC DECAPODA IN CHINA
}

\begin{abstract}
Yitao Pan ${ }^{1,2}$, Zhonge Hou', and Shuqiang Li ${ }^{1 *}$
Abstract: Macrobrachium elegantum is a new species of stygobiotic shrimp discovered in Guangxi, China. The new species is characterized by a transparent body and degenerated eyes and is morphologically similar to M. lingyunense. This is an addition to the list of fifteen stygobiotic shrimp previously known from throughout the karst of China.
\end{abstract}

\section{INTRODUCTION}

Karst landforms cover about 33\% of China's surface. Caves can be found in most karst areas, especially in Yunnan, Guizhou, and Guangxi provinces. This karst terrain has numerous varieties of cave-dwelling animals, including bats, amphibians, fishes, spiders, and crustaceans (Li, 2007). Geographically disjunct, small, and island-like cave populations in many parts of the world are imperiled by declining water supply and quality as a result of human activities. These include groundwater pumping, tourism, pollution, and nutrient enrichment (Eberhard et al., 2005). Cave species in the Chinese karst regions are threatened by similar factors. Some cave vertebrates have been listed as endangered species and conservation rules have been issued, but stygobiotic invertebrates are poorly studied and less attention has been paid to protecting them.

The study of Chinese cave-dwelling species of Decapoda began about fifteen years ago. A total number of fifteen stygobiotic species of shrimp were recorded (Liang, 2004; Li et al., 2006). In 2008, a scientific expedition to the Guangxi karst regions was organized by the Guangxi Institute of Fisheries and several specimens of stygobiotic Decapoda were collected. Close study of the specimens revealed the presence of a new species of the genus Macrobrachium Bate, 1868. In this study, we review the diversity, adaptation, and distribution of cave Decapoda in China and describe the new taxon, Macrobrachium elegantum n. sp.

\section{DiverSITY AND Distribution OF Stygobiotic Decapoda}

With the addition of the new species described here, there are 17 stygobiont species of Decapoda recorded in China, of which 15 belong to three genera of the family Atyidae and two to the family Palaemonidae (Table 1). These species are scattered in China's karst regions and there are large areas that have not been fully investigated by scientists (Fig. 1). Therefore we believe that more cavedwelling decapods will be found in the future.
Compared to the surface biotope, ecosystems in caves are usually characterized by aphotic conditions, tenuous air, and stable temperature. Animals living in such environments often possess the adaptive modifications of troglobites, such as long, slender body and appendages (Espinasa and Vuong, 2008). Cavernicolous species of Macrobrachium may invade caves independently, but convergent evolution has resulted in similar life history (Wowor et al., 2009). Cave decapods in China show adaptive changes in eyes, coloration, and body shape. Table 1 provides a list of known species of stygobiotic decapods from China and their different adaptations to the cave environment.

\section{Material And Methods}

Specimens were collected by electrofishing, preserved in $75 \%$ ethanol, examined using an SZX12-Olympus stereomicroscope, and measured by slide caliper. Detailed observations were made under a BX41-Olympus compound microscope and a $\mathrm{BH} 2$-Olympus microscope. All illustrations were produced using a camera lucida. Male pereopods were examined and illustrated after being detached. Size of specimens is indicated by carapace length (CL) measured from the orbital margin to the posterodorsal margin. All measurements are given in millimeters $(\mathrm{mm})$. Terminology for somatic morphology is after Komai and Fujita (2005). All type specimens and other material are deposited in the Institute of Zoology, Chinese Academy of Sciences (IZCAS), Beijing, China.

\section{TAXONOMY}

Macrobrachium elegantum n. sp. (Figs. 1-4)

\section{MATERIAL EXAMined}

Holotype: male (IZCAS-DE-005), CL $15.2 \mathrm{~mm}$, an unnamed cave in Xiaorui Village, Ludong Town, Jingxi County

\footnotetext{
*Corresponding Author, lisq@ioz.ac.cn

${ }^{1}$ Institute of Zoology, Chinese Academy of Sciences, Beijing 100101, China

${ }^{2}$ College of Environment and Resources, Jilin University, Changchun 130012, China
} 
Table 1. The known stygobiotic Decapoda from China.

\begin{tabular}{|c|c|c|c|}
\hline Species & Type locality & $\begin{array}{l}\text { Latitude and } \\
\text { Longitude }\end{array}$ & Habitat and morphological adaptation \\
\hline \multicolumn{4}{|c|}{ Atyidae } \\
\hline $\begin{array}{l}\text { Caridina guangxiensis Liang } \\
\text { and Zhou, } 1993\end{array}$ & $\begin{array}{l}\text { Tianwangshan Cave, } \\
\text { Guilin, Guangxi (1) }\end{array}$ & $\begin{array}{l}25.20^{\circ} \mathrm{N} \\
110.30^{\circ} \mathrm{E}\end{array}$ & $\begin{array}{l}\text { Found in groundwater of cave, without } \\
\text { light; body pink and transparent, eyes } \\
\text { normal, cornea developed. }\end{array}$ \\
\hline $\begin{array}{l}\text { Caridina feixiana Cai and } \\
\text { Liang, } 1999\end{array}$ & $\begin{array}{l}\text { Feixia Cave, Gejiu, } \\
\text { Yunnan (2) }\end{array}$ & $\begin{array}{l}23.35^{\circ} \mathrm{N} \\
103.15^{\circ} \mathrm{E}\end{array}$ & $\begin{array}{l}\text { In completely dark zone of cave; eyes } \\
\text { normal. }\end{array}$ \\
\hline $\begin{array}{l}\text { Caridina cavernicola Liang } \\
\text { and Zhou, } 1993\end{array}$ & $\begin{array}{l}\text { Lenggu Cave, Du'an, } \\
\text { Guangxi (3) }\end{array}$ & $\begin{array}{l}24.20^{\circ} \mathrm{N} \\
108.13^{\circ} \mathrm{E}\end{array}$ & $\begin{array}{l}\text { In groundwater of cave, } 30 \text { meters away } \\
\text { from entrance, no light; eyes normal, } \\
\text { cornea developed. }\end{array}$ \\
\hline $\begin{array}{l}\text { Caridina dianchiensis Liang } \\
\text { and Yan, } 1985\end{array}$ & $\begin{array}{l}\text { Huahong Cave, } \\
\text { Kunming, Yunnan (4) }\end{array}$ & $\begin{array}{l}25.67^{\circ} \mathrm{N} \\
102.67^{\circ} \mathrm{E}\end{array}$ & $\ldots$ \\
\hline Caridina mengae Liang, 1993 & $\begin{array}{l}\text { Xiangshui Cave, Panshi, } \\
\text { Songtao, Guizhou (5) }\end{array}$ & $\begin{array}{l}28.15^{\circ} \mathrm{N} \\
109.2^{\circ} \mathrm{E}\end{array}$ & $\cdots$ \\
\hline $\begin{array}{l}\text { Caridina ablepsia Guo, } \\
\text { Jiang and Zhang, } 1992\end{array}$ & $\begin{array}{l}\text { Xiaolong Cave, } \\
\text { Yongshunwang Village, } \\
\text { Hunan (6) }\end{array}$ & $\begin{array}{l}29.00^{\circ} \mathrm{N} \\
109.85^{\circ} \mathrm{E}\end{array}$ & $\begin{array}{l}\text { In groundwater of cave, completely dark; } \\
\text { eyes small, reduced, cornea non- } \\
\text { pigmented, body ivory. }\end{array}$ \\
\hline $\begin{array}{l}\text { Caridina semiblepsia Guo, } \\
\text { Choy and Gui, } 1996\end{array}$ & $\begin{array}{l}\text { Baojing Cave, Baojing, } \\
\text { Hunan (7) }\end{array}$ & $\begin{array}{l}28.70^{\circ} \mathrm{N} \\
109.65^{\circ} \mathrm{E}\end{array}$ & $\begin{array}{l}\text { In completely dark zone of cave; eye-stalk } \\
\text { degenerated, body transparent. }\end{array}$ \\
\hline $\begin{array}{l}\text { Caridina demenica Cai and } \\
\quad \mathrm{Li}, 1997\end{array}$ & $\begin{array}{l}\text { Demen Cave, Yongkang } \\
\text { Village, Libo, Guizhou (8) }\end{array}$ & $\begin{array}{l}25.37^{\circ} \mathrm{N} \\
107.90^{\circ} \mathrm{E}\end{array}$ & Eyes reduced with small pigment. \\
\hline $\begin{array}{l}\text { Caridina caverna Liang, } \\
\text { Chen and } \mathrm{Li}, 2005\end{array}$ & $\begin{array}{l}\text { Xiaoshui Cave, Maolan, } \\
\text { Guizhou (9) }\end{array}$ & $\begin{array}{l}25.33^{\circ} \mathrm{N} \\
107.93^{\circ} \mathrm{E}\end{array}$ & $\begin{array}{l}\text { In groundwater of cave, no light; cornea } \\
\text { non-pigmented. }\end{array}$ \\
\hline $\begin{array}{l}\text { Caridina acuta Liang, Chen } \\
\text { and } \mathrm{Li}, 2005\end{array}$ & $\begin{array}{l}\text { Labiaoqiao Cave, Maolan, } \\
\text { Guizhou (10) }\end{array}$ & $\begin{array}{l}25.33^{\circ} \mathrm{N} \\
107.93^{\circ} \mathrm{E}\end{array}$ & $\begin{array}{l}\text { In a cave with weak light; cornea } \\
\text { degenerated, with pigment. }\end{array}$ \\
\hline $\begin{array}{l}\text { Typhlocaridina lanceifrons } \\
\text { Liang and Yan, } 1981\end{array}$ & $\begin{array}{l}\text { Daji Cave, Qifeng } \\
\text { Mountain, Wuming, } \\
\text { Guangxi (11) }\end{array}$ & $\begin{array}{l}23.21^{\circ} \mathrm{N} \\
108.21^{\circ} \mathrm{E}\end{array}$ & $\begin{array}{l}\text { In limpid groundwater of cave, } \\
\text { completely dark; the whole body ivory, } \\
\text { no eyes, cornea non-pigmented. }\end{array}$ \\
\hline $\begin{array}{l}\text { Typhlocaridina liui Liang } \\
\text { and Zhou, } 1993\end{array}$ & $\begin{array}{l}\text { Paobing Cave, Lingui, } \\
\text { Guangxi (12) }\end{array}$ & $\begin{array}{l}25.25^{\circ} \mathrm{N} \\
110.05^{\circ} \mathrm{E}\end{array}$ & $\begin{array}{l}\text { In the entrance of cave, with weak light; } \\
\text { eyes degenerated, with } 3 \text { black } \\
\text { pigments. }\end{array}$ \\
\hline $\begin{array}{l}\text { Typhlocaridina semityphlata } \\
\text { Cai, } 1995\end{array}$ & $\begin{array}{l}\text { A cave in Guilin, } \\
\text { Guangxi (13) }\end{array}$ & $\begin{array}{l}25.283^{\circ} \mathrm{N} \\
110.283^{\circ} \mathrm{E}\end{array}$ & $\begin{array}{l}\text { In caves; eyes reduced, pigment in cornea } \\
\text { degenerated to a small black dot. }\end{array}$ \\
\hline $\begin{array}{l}\text { Typhlocaridina lingyunensis } \\
\mathrm{Li} \text { and Luo, } 2001\end{array}$ & Lingyun, Guangxi (14) & $\begin{array}{l}24.38^{\circ} \mathrm{N} \\
106.63^{\circ} \mathrm{E}\end{array}$ & $\begin{array}{l}\text { Eyes degenerated and small, cornea non- } \\
\text { pigmented. }\end{array}$ \\
\hline $\begin{array}{l}\text { Neocaridina brevidactyla } \\
\text { Liang, Chen and Li, } 2005\end{array}$ & $\begin{array}{l}\text { Xiaoshui Cave, Maolan, } \\
\text { Guizhou (15) }\end{array}$ & $\begin{array}{l}25.33^{\circ} \mathrm{N} \\
107.93^{\circ} \mathrm{E}\end{array}$ & In a cave; eyes normal, cornea developed \\
\hline \multicolumn{4}{|c|}{ Palaemonidae } \\
\hline $\begin{array}{c}\text { Macrobrachium lingyunense } \\
\text { Li, Cai and Clarke, } 2006\end{array}$ & $\begin{array}{l}\text { Shadong (Sand cave), } \\
\text { Lingyun, Guangxi (16) }\end{array}$ & $\begin{array}{l}24.38^{\circ} \mathrm{N} \\
106.63^{\circ} \mathrm{E}\end{array}$ & $\begin{array}{l}\text { Eyes degenerated, cornea non-pigmented, } \\
\text { body transparent. }\end{array}$ \\
\hline $\begin{array}{l}\text { Macrobrachium elegantum } \\
\text { n. sp. }\end{array}$ & $\begin{array}{l}\text { A cave in Jingxi, } \\
\text { Guangxi (17) }\end{array}$ & $\begin{array}{l}23.10^{\circ} \mathrm{N} \\
106.4^{\circ} \mathrm{E}\end{array}$ & $\begin{array}{l}\text { In caves; eyes degenerated and small, } \\
\text { cornea non-pigmented, body } \\
\text { transparent. }\end{array}$ \\
\hline
\end{tabular}

$\left(23.1^{\circ} \mathrm{N}, 106.4^{\circ} \mathrm{E}\right)$, Guangxi Zhuang Autonomous Region, China; March 3, 2008, collected by Chunguang Zhang.

Paratypes: one male (IZCAS-DE-006), CL $12.8 \mathrm{~mm}$; two females (IZCAS-DE-007, 008), CL $14.7 \mathrm{~mm}, 15.2 \mathrm{~mm}$, same data as holotype.

\section{DiAgnosis}

Rostrum straight, tip bifurcate and reaching beyond distal margin of scaphocerite, dorsal margin armed with seven or eight teeth, including three or four on carapace behind orbital margin; teeth placed more widely on anterior part; ventral margin armed with four to six teeth. Inferior orbital lobe typical for genus, produced in roundly triangular, overhung lobe. Antennal spine behind inferior orbital angle; hepatic spine inferior to antennal spine. First to fifth abdominal sternites with distinct transverse ridge, tooth of fifth larger. Telson terminating in sharp tooth posteriorly, with two pairs of dorsolateral spines; terminal 
Description of a new Macrobrachium species (Crustacea: Decapoda: Caridea: Palaemonidae) from a cave in Guangxi, with a SYNOPSIS OF THE STYGOBIOTIC DECAPODA IN CHINA

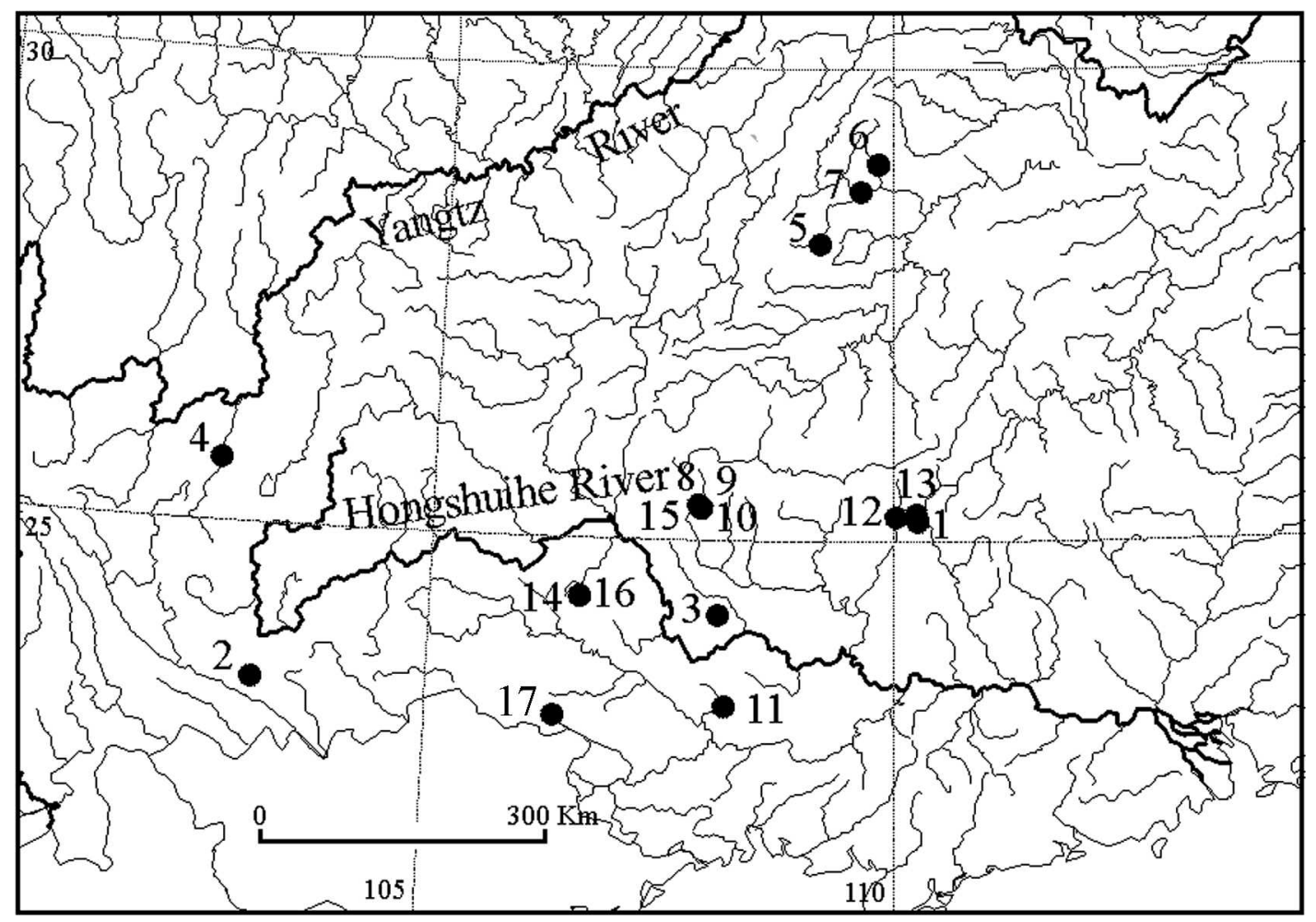

Figure 1. Localities of Chinese stygobiotic Decopoda (the numbers are the same as in Table 1).

tooth not overreaching posterolateral spines. Epistome not bilobed. Eyes small, stalks highly reduced, cornea nonpigmented. Lateral margin of scaphocerite straight. Carpus of first pereopod 1.7 times as long as chela. Second pereopod symmetrically equal, surface of segments smooth; chela about 1.9 times longer than carpus; fingers about 1.6 times longer than palm, dactylus slightly longer than fixed finger, with tips crossing when closed; cutting edges with rows of setae, no tooth. Palm subcylindrical, shorter than carpus, inflated. Carpus subequal in length to merus. Third pereopod slender, reaching beyond distal margin of scaphocerite by 0.3 times the length of propodus, carpus distinctly shorter than propodus.

\section{Description of Holotype Male}

Body moderately robust. Rostrum (Fig. 2A-C) straight, tip bifurcate with setule, reaching slightly beyond distal margin of scaphocerite, 0.7 times as long as the carapace. Dorsal margin armed with eight teeth, including four on carapace behind posterior margin of orbit, arising from about 0.4 times the carapace length; anterior teeth larger than posterior, spaces between first, second, and third teeth distinctly wider than others; ventral margin armed with four teeth, rows of plumose setae present between each tooth on dorsal and ventral margin. Inferior orbital angle produced in roundly triangular lobe, conspicuous. Antennal spine (Fig. 2A-B) moderately small, submarginal, situated inferior to inferior orbital angle, tip not reaching anterolateral margin of carapace; hepatic spine smaller than antennal spine, lying slightly inferior to level of it. Surface of carapace (Fig. 2A) smooth, glabrous.

Thoracic sternum narrow; fourth to fifth thoracic sternites with indistinct transverse ridge; sixth to seventh sternites with transverse ridge along posterior border; eighth thoracic sternite with distinct oblique transverse ridges along posterior border.

Abdomen smooth and glabrous (Fig. 3A); first to third and fifth pleurae with posterolateral margins produced roundly, those of fourth with feeble posterior process; sixth abdominal somite 1.4 times as long as fifth somite. First to fifth abdominal sternites with distinct transverse ridges; fourth and fifth abdominal sternites with transverse ridges and median teeth, that of fifth abdominal sternites larger. Telson (Fig. 2E) 1.2 times as long as the sixth abdominal somite, with two pairs of spines (at $70 \%$ and $85 \%$ of total length measured from posterior tooth, respectively); posterior margin terminating in acute tooth $(=$ posteromedian tooth), flanked by two pairs of spines, inner pair about 3 times longer than lateral pair; four pairs of plumose setae arising from ventral surface of posteromedian tooth; all four pairs of setae as long as inner pair of spines, distinctly longer than lateral pair of spines.

Epistome not bilobed (Fig. 4I).

Eyes highly reduced (Fig. 2A-C); cornea elliptical, small and non-pigmented, eye-stalks degenerated.

Antennular peduncle (Fig. 2B, C) reaching 0.8 times the length of scaphocerite. Basal segment moderately broad, about 2 times as wide as second segment, as long as wide, 


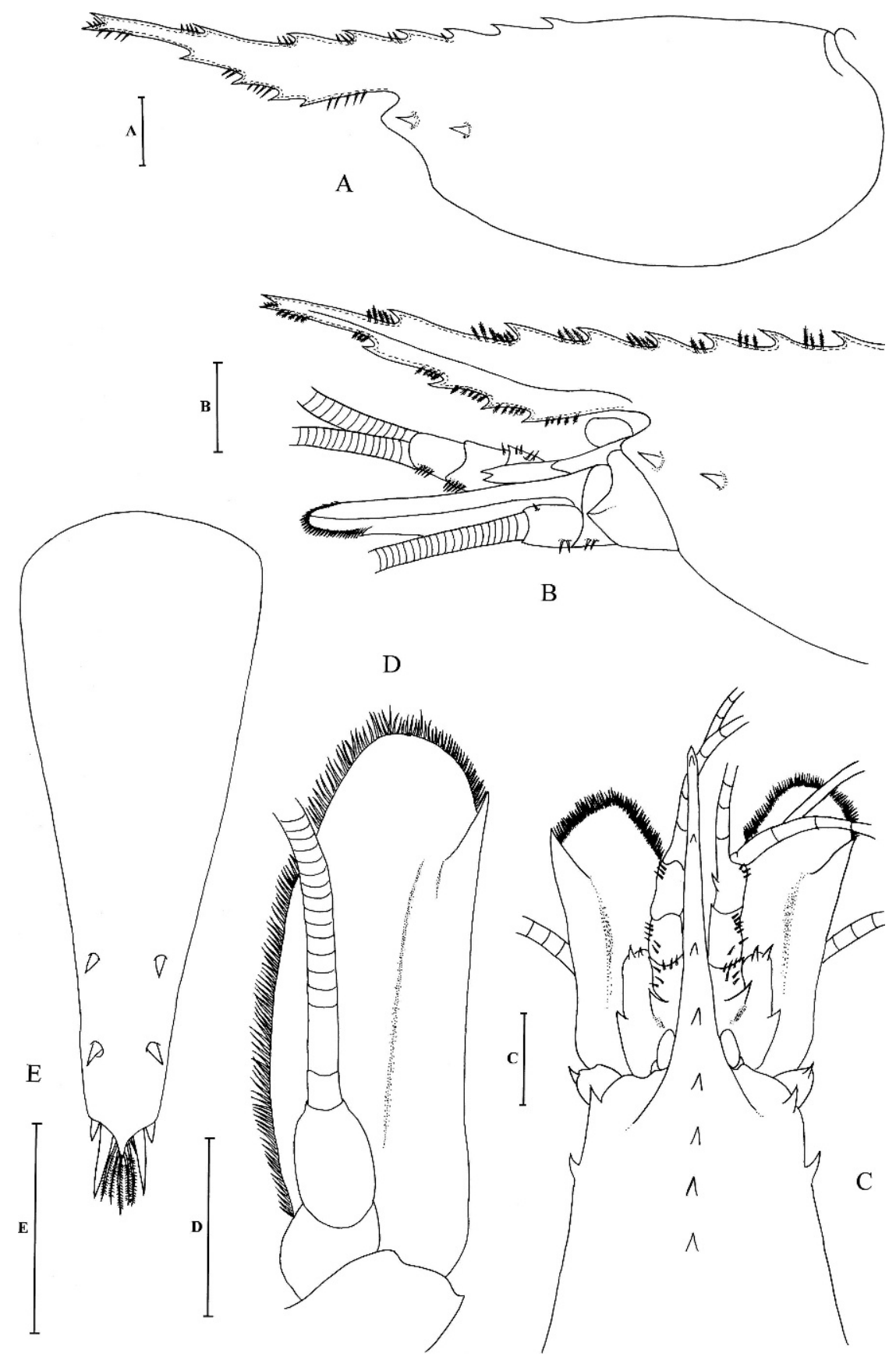

Figure 2. Macrobrachium elegantum $\mathrm{n}$ sp., holotype, male. A, rostrum and carapace, lateral view. B, rostrum, anterior part of carapace and cephalic appendages, lateral view. C, rostrum, anterior part of carapace and cephalic appendages, dorsal view. D, antenna, ventral view. E, telson, dorsal view. Scale bars: $2 \mathrm{~mm}$.

lateral margin straight, with a small proximal tooth, anterolateral angle produced in two sharp spines overreaching distal margin of basal segment, dorsal surface weakly concave, with few short setae; ventral edge tapering posteriorly; stylocerite short and sharp, reaching about 0.5 times the length of second segment. Second segment about 0.6 times as long as basal segment, about 1.6 times as long as wide, ventral edge with row of setae. Third segment slightly longer than second segment, about
1.8 times as long as wide. Lateral flagellum biramous, longer ramus 2.5 times the carapace length, shorter ramus (accessory flagellum) about 0.5 times the length of longer ramus.

Antennal peduncle (Fig. 2B, D) with tooth on ventrolateral margin of basicerite. Fifth segment (carpocerite) cylindrical, reaching $30 \%$ of scaphocerite length. Scaphocerite (Fig. 2D) about 50\% of carapace length, 3 times longer than broad; lateral margin straight, terminating in 
Description of a new Macrobrachium species (Crustacea: Decapoda: Caridea: Palaemonidae) from a cave in Guangxi, with a SYNOPSIS OF THE STYGOBIOTIC DECAPODA IN CHINA

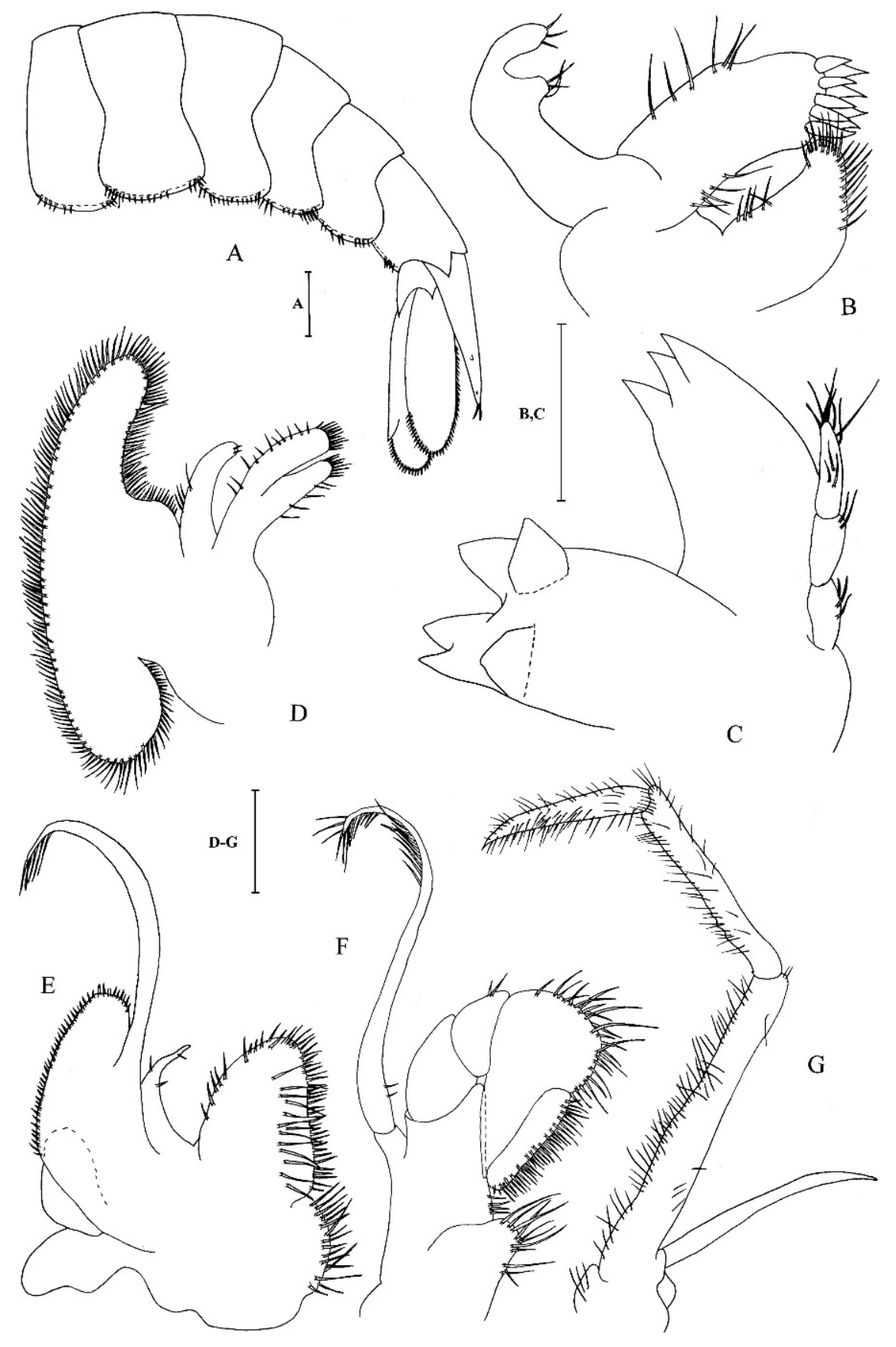

Figure 3. Macrobrachium elegantum n. sp. holotype, male. A, abdomen and left uropod, lateral view. B, maxillule. C, mandible. D, maxilla. E, first maxilliped. F, second maxilliped. G, third maxilliped. Scale bars: A, 2 mm; B-G, 1 mm.

small distolateral tooth far exceeded by broadly rounded lamella. Flagellum 1.6 times of body length.

Mouthparts typical for genus. Mandible (Fig. 3C) with slender palp consisting of three articles; incisor process robust, armed with three moderate teeth; molar process robust, truncate distally, with four principal peripheral teeth; maxillule (Fig. 3B) with palp weakly bilobed, outer lobe somewhat elongate; inner lobe short, rounded, two lobes with three setae distally; coxal endite extending as far as basial endite, tapering to truncate tip distally, surface with stiff setae; basial endite trapeziform, broad, with nine large spines and stiff setae on truncate distal margin. Maxilla (Fig. 3D) with coxal endite obsolete; basial endite consisting of two slender lobes, anterior lobe bearing setae on dorsal margin, posterior lobe with setae on ventral margin, both lobes with numerous short setae distally, setae on dorsal and ventral margin longer than those distally; palp with basal part moderately broad, tapering distally; scaphognathite broad, anterior lobe large, posterior lobe moderately narrow, both lobes rounded. First 


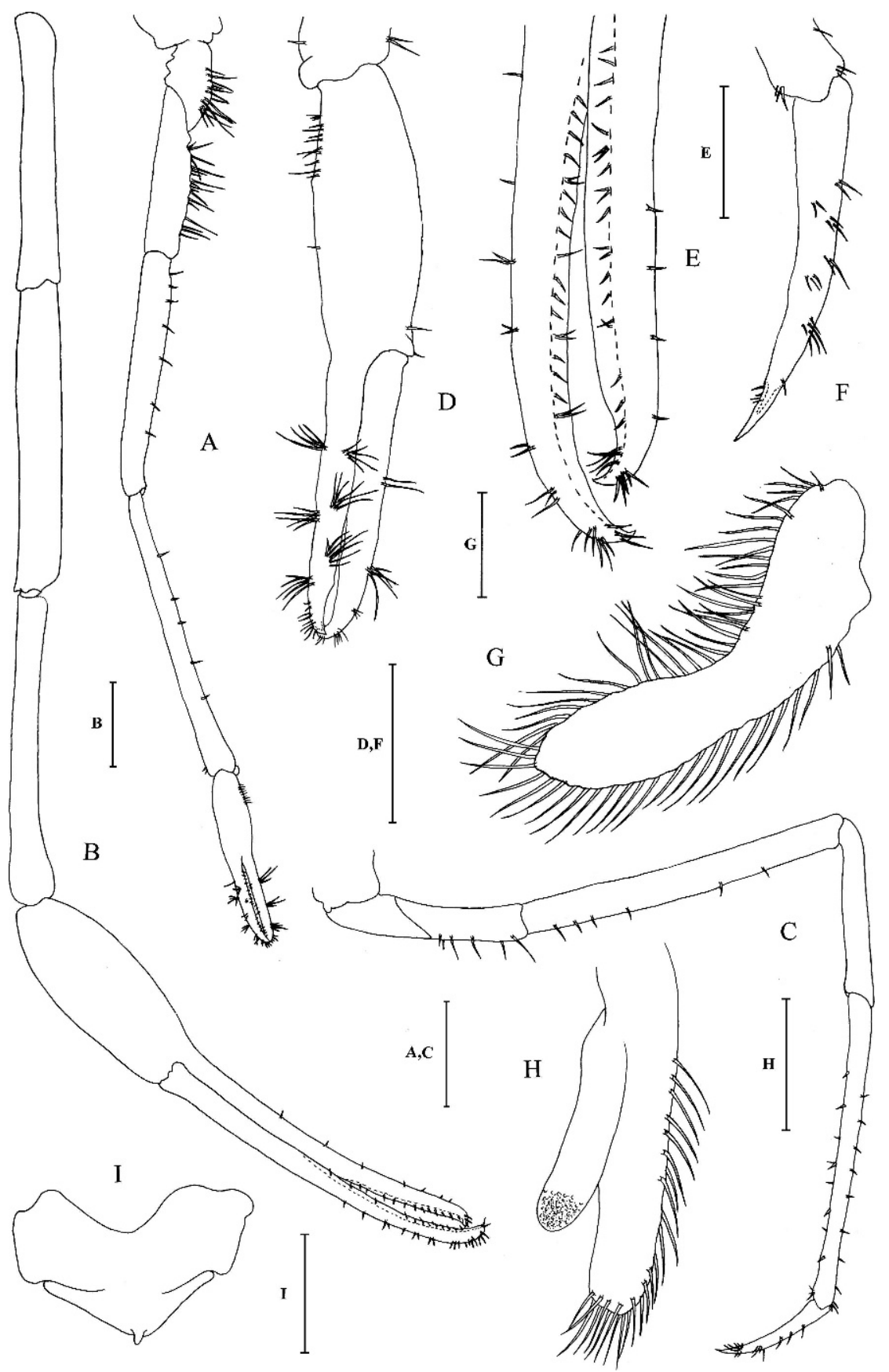

Figure 4. Macrobrachium elegantum n. sp. holotype, male. A, first pereopod. B, second pereopod. C, third pereopod. D, chela of first pereopod. E, tips of fingers of second pereopod. F, dactylus of third pereopod. G, endopod of first pleopod. H, appendix interna and appendix masculina of second pleopod. I, epistome. Scale bars: A-C 2 mm, D-F, I, 1 mm; G-H, 0.5 mm.

maxilliped (Fig. 3E) with setose coxal endite; basial endite subtriangular; palp with few setae, simple and slender, not reaching the distal margin of basial endite; exopod well developed, with long flagellum, caridean lobe moderately broad with row of short setae on margin; epipod with two broad lobes, both tapering distally. Second maxilliped (Fig. 3F) with dactylus and propodus partially fused; ischium and basis fused; coxa with long setae; exopod long and slender, with several setae distally; epipod moderately simple with well-developed podobranch. Third maxilliped (Fig. 3G) with robust endopod; coxa stout, ischiomeral (antepenultimate) segment incompletely fused to basis, combined length about 6.3 times longer than greatest height, with surface bearing tufts of long setae; penultimate segment 0.6 times the length of ischiomeral segment, 6 times longer than distal height, with low protuberances and tufts of setae on ventral margin; ultimate segment 0.8 times the length of carpus, 6 times 
Description of a new Macrobrachium species (Crustacea: Decapoda: Caridea: Palaemonidae) from a cave in GuangXi, with a SYNOPSIS OF THE STYGoBiotic DeCAPODA IN CHINA

longer than greatest height, with numerous stiff setae, exopod well developed, reaching 0.6 times the length of ischiomeral segment.

First pereopod (Fig. 4A) moderately slender, reaching beyond scaphocerite by entire chela and $10 \%$ of carpus; chela (Fig. 4D) 5 times longer than width, fingers 1.1 times longer than palm, terminating in small, curved claws; cutting edge smooth; palm subcylindrical, with setae ventrally; carpus 1.6 times longer than chela, 16.3 times longer than wide; merus about 0.8 times as long as carpus, ischium about 0.6 times the length of merus.

Second pereopod (Fig. 4B) symmetrically equal, overreaching distal margin of scaphocerite by length of chela and carpus; chela slender, 6.3 times as long as the greatest width. Surface of dactylus (Fig. 4E) with a few regularly arranged setae; dactylus slender, 2 times the length of palm, terminating in a small curved claw; cutting edge thin; fixed finger with one row of short setae rising from edge subequally spaced, cutting edge thin and smooth; dactylus longer than fixed finger, with tips crossing when closed; fingers not gaping when closed; palm subcylindrical, 2.2 times as long as maximal height, swollen with ventral margin convex. Carpus slightly widened distally, 0.5 times the chela length, 1.5 times the palm length, subequal in length to merus, smooth, without setae on surface, present also on merus and ischium; merus shorter and wider, nearly as long as carpus; ischium 0.9 times the length of merus.

Third pereopod (Fig. 4C) reaching beyond scaphocerite by $30 \%$ the length of propodus; dactylus (Fig. 4F) 0.3 times the propodus length, 6.1 times longer than proximal width, slightly curved, ending with small unguis, lateral surface of dactylus with four tufts of short setae and several single setae along dorsal margin; propodus 1.7 times carpus length, 16 times longer than distal width, with one row of short setae on dorsal margin, present also on ventral margin; carpus 0.5 times of merus length, smooth on dorsal margin; ventral margin of merus and ischium with few short setae.

Fourth and fifth pereopods missing.

Endopod (Fig. 4G) of first pleopod about 0.4 times of exopod length, weakly broadened distally, somewhat curved medially, margins fringed with setae and low protuberances; appendix masculina (Fig. 4H) of second pleopod longer than appendix interna, with numerous spiniform bristles on dorsal margin. Appendix interna exceeding 0.7 times of appendix masculina.

Exopod (Fig. 3A) of uropod overreaching tip of telson by 0.3 times of length, lateral margin straight, ending by small acute tooth; endopod slightly shorter than exopod.

\section{Description of Allotype (IZCAS-DE-007) Female}

Rostrum 0.6 times carapace length, dorsal margin armed with seven or eight teeth, including three or four on carapace posterior to level of orbital margin; ventral margin with four or five teeth. Second pereopod symmet- rical; similar in structure with male; dactylus 1.7 times longer than palm; chela 1.7 times longer than carpus; palm shorter than carpus; merus 1.1 times longer than carpus.

\section{DisTRIBUTION}

So far, only known from the type locality.

\section{ETYMOLOGY}

The species name elegantum alludes to its beautiful body shape. It is an adjective agreeing in gender with the (neuter) generic name.

\section{REMARKS}

The genus Macrobrachium Bate, 1868, is the most diverse genus of freshwater palaemonid shrimps in China (Liu et al., 1990). Most species are found in surface waters, but two occur in caves. The stygobiotic species can be easily distinguished from others by their highly reduced eyes with unpigmented corneas and the absence of eyestalk. The new species is closely related to $M$. lingyunense $\mathrm{Li}$ et al. (2006). Both share similar characters in the second pereopod, including smooth surfaces on the segments and a subcylindrical palm. The new species differs from $M$. lingyunense in the following combination of characters: The rostrum reaches beyond the distal margin of the scaphocerite, 0.7 times the carapace length, while in $M$. lingyunense the rostrum reaches just slightly beyond the distal margin of the scaphocerite, 0.5 times the carapace length. The rostrum is straight, with bifurcate tip, while that of $M$. lingyunense is directed forward. The rostrum formula is 3-4+4/4-6, but 3-4+4-5/3-4 in $M$. lingyunense. The palm of the second pereopod is much more inflated than that of congener. The fingers are about twice as long as the palm, the dactylus is longer than fixed finger, and they cross when fingers are closed, with no gaping or tooth, but in $M$. lingyunense the fingers are about 1.5 times longer than the palm, and the cutting edge of dactylus has a small transparent proximal tooth. The chela is 0.5 times the carpus length and 1.5 times the palm length, and the merus is wider, nearly as long as the carpus, while in $M$. lingyunense the chela is 1.9 to 2.1 times longer than the carpus, the palm is shorter than the carpus, and the latter is subequal in length to the merus. And the inferior orbital lobe is subtriangular, which is typical for the genus, while being poorly developed and hardly recognizable in $M$. lingyunense.

\section{ACKNOWLEDGEMENTS}

The manuscript benefited greatly from comments by Malcolm S. Field (U. S. Environmental Protection Agency, National Center for Environmental Assessment-Washington Office, Washington, DC), John E. Cooper (North Carolina State Museum of Natural Sciences, USA) and one anonymous reviewer. This study was supported by the National Natural Sciences Foundation of China (NSFC- 
$30499341 / 30670239 / 30870271 / 30770268 / 30870473)$, by the National Science Fund for Fostering Talents in Basic Research (Special Subjects in Animal Taxonomy, NSFCJ0630964/J0109), by the Knowledge Innovation Program of the Chinese Academy of Sciences (KSCX2-YW-Z-008/ KSCX3-IOZ-0811), by the Ministry of Science and Technology of the People's Republic of China (MOST grant no. 2006FY120100/2006FY110500), and also partly by the Beijing Natural Science Foundation (5082013).

\section{REFERENCES}

Bate, C.S., 1868, On a new genus, with four new species of freshwater prawns, in Proceedings of the Zoological Society of London, v. 1868, p. $363-368$, pls. 30,31 .

Cai, Y.X., 1995, A new troglobitic shrimp from China: Acta Zootaxonomica Sinica, v. 20, no. 2, p. 157-160.

Cai, Y.X., and Li, S.Q., 1997, Caridina demenica, a new species of troglobitic shrimp (Crustacea: Decapoda: Atyidae) from Guizhou, China: The Raffles Bulletin of Zoology, v. 45, no. 2, p. 315-318.

Cai, Y.X., and Liang, X.Q., 1999, Descriptions of three new species of freshwater shrimps (Crustacea: Decapoda: Atyidae) from Yunnan, Southern China: The Raffles Bulletin of Zoology, v. 47, no. 1, p. 73-80.

Eberhard, S., Leys, R., and Adams, M., 2005, Conservation of subterranean biodiversity in Western Australia: Using molecular genetics to define spatial and temporal relationships in two species of cave-dwelling Ampipoda: Subterranean Biology, v. 3, p. 13-27.

Espinasa, L., and Vuong, N.H., 2008, A new species of cave adapted nicoletiid (Zygentoma: Insecta) from Sistema Huautla, Oaxaca, Mexico: The tenth deepest cave in the world: Journal of Cave and Karst Studies, v. 70, no. 2, p. 73-77.

Guo, Z.L., Choy, S.C., and Gui, Q.M., 1996, Caridina semiblepsia, a new species of troglonic shrimp (Crustacea, Decapoda, Atyidae) from Hunan Province, China: The Raffles Bulletin of Zoology, v. 44, no. 1, p. $1-10$.
Guo, Z.L., Jiang, H., and Zhang, M.S., 1992, A new species of Caridina from Hunan, China (Decapoda, Atyidae): Sichuan Journal of Zoology, v. 11, no. 2, p. 4-6.

Komai, T., and Fujita, Y., 2005, A new stygiobiont species of Macrobrachium (Crustacea: Decapoda: Caridea: Palaemonidae) from an anchialine cave on Miyako Island, Ryukyu Islands: Zootaxa, v. 1021, p. $13-27$

Li, D.H., 2007, Cave animals from karst region of Guizhou Province, Beijing, Geological Publishing House, 190 p.

Li, J.C., Cai, Y.X., and Clarke, A., 2006, A new species of troglobitic freshwater prawn of the genus Macrobrachium from Southern China (Crustacea: Decapoda: Palaemonidae): The Raffles Bulletin of Zoology, v. 54, no. 2, p. 277-282.

Li, W.X., and Luo, Z.F., 2001, A new troglobitic shrimp from Guangxi: Journal of Guangxi Normal University, v. 19, no. 2, p. 72-74.

Liang, X.Q., 1993, Two new species of Caridina from Guizhou, China: Acta Zootaxonomica Sinica, v. 18, no. 1, p. 22-26.

Liang, X.Q., 2004, Fauna Sinica, Invertebrata, Crustacea, Decapoda, Atyidae, Beijing, Science Press, 375 p.

Liang, X.Q., Chen, H.M., and Li, W.X., 2005, Three new species of atyid shrimps (Decapoda, Caridea) from caves of Guizhou, China: Acta Zootaxonomica Sinica, v. 30, no. 3, p. 529-534.

Liang, X.Q., and Yan, S.L., 1981, A new genus and two new species of freshwater prawns (Crustacea, Decapoda) from Guangxi, China: Acta Zootaxonomica Sinica, v. 6, no. 10, p. 1-21.

Liang, X.Q., and Yan, S.L., 1985, Study on Caridina (Decapoda, Caridea) from Yunnan, China: Oceanologia and Limnologia Sinica, v. 16, no. 2, p. 164-174

Liang, X.Q., and Zhou, J., 1993, Study on new atyid shrimps (Decapoda, Caridea) from Guangxi, China: Acta Hydrobiologia Sinica, v. 17, no. 3 , p. $231-239$

Liu, R.Y., Liang, X.Q., and Yan, S.L., 1990, A study of the Palaemoninae (Crustacea, Decapoda) From China I. Macrobrachium, Leander and Leandrites: Transactions of the Chinese Crustacean Society II, p. $102-134$.

Wowor, D., Muthu, V., Meier, R., Balke, M., Cai, Y.X., and Ng, P.K.L., 2009, Evolution of life history traits in Asian freshwater prawns of the genus Macrobrachium (Crustacea: Decapoda: Palaemonidae) based on multilocus molecular phylogenetic analysis: Molecular Phylogenetics and Evolution, v. 52, no. 2, p. 340-350. 